\title{
Diet and parasites of the insular fish Scartichthys variolatus (Blenniidae) from Robinson Crusoe Island, Chile: How different is this from two continental congeneric species?
}

Dieta y parásitos del pez insular Scartichthys variolatus (Blenniidae) de la Isla Robinson Crusoe, Chile: ¿qué tanto difiere con la de dos congéneres continentales?

\begin{abstract}
Pablo E. Díaz ${ }^{1}$ and Gabriela Muñoz ${ }^{2}$
${ }^{1}$ Departamento de Biología Marina, Facultad de Ecología y Recursos Naturales, Universidad Andres Bello, República 440, Santiago, Chile.pabl.diaz@uandresbello.edu

${ }^{2}$ Facultad de Ciencias del Mar y de Recursos Naturales, Universidad de Valparaíso, Casilla 5080, Viña del Mar, Chile

Resumen.- En este estudio se analizó la dieta y parásitos del pez blénido insular Scartichthys variolatus y se le comparó con datos publicados de dos congéneres continentales de la costa Pacífica de Sudamérica, S. viridis y S. gigas. Cincuenta y dos especímenes de $S$. variolatus fueron recolectados desde la zona intermareal de la Isla Robinson Crusoe, ubicada a $700 \mathrm{~km}$ de la costa de Chile central, entre el 2008 y 2009. Las algas fueron los ítemes dietarios de mayor frecuencia, presentes en todos los ejemplares analizados. Sólo dos ejemplares de S. variolatus $(3,8 \%)$ estuvieron parasitados únicamente por el nemátodo Pseudodelphis chilensis. A pesar de que todas las especies de Scartichthys spp. son herbívoras y su dieta se compone por especies de algas similares, se detectaron diferencias en la frecuencia de ocurrencia para algunas algas, principalmente en Chaetomorpha sp. y Polysiphonia sp. La baja riqueza parasitaria de S. variolatus contrasta notablemente con la de sus congéneres continentales, S. viridis y S. gigas, cada una con 13 especies de parásitos. Por lo tanto, las diferencias dietarias no son suficientes para explicar las diferencias parasitarias entre el pez insular y la de sus congéneres. Es posible que las diferencias ambientales y la distancia que separa la isla Robinson Crusoe de la costa Pacífico de Sudamérica limitaran la dispersión de parásitos y de hospedadores a lo largo del tiempo.
\end{abstract}

Palabras clave: Archipiélago Juan Fernández, dispersión de parásitos, peces blénidos, riqueza de especies parásitas

Abstract.- This study analyzed the diet and parasites of an insular blenniid fish, Scartichthys variolatus, and then compared that with data published for two congeneric species from the South American Pacific coast, S. viridis and S. gigas. Fifty-two specimens of fish were collected during 2008 and 2009 from the intertidal zone of the Robinson Crusoe Island, about $700 \mathrm{~km}$ off the coast of central Chile. The most frequent food items in all the fish analyzed were algae. Just two specimens of S. variolatus (3.8\%) were parasitized only by the nematode Pseudodelphis chilensis. Despite the fact that all Scartichthys spp. are herbivorous, and the diet was composed of similar species, there were differences in frequencies of some of the algae, maily in Chaetomorpha sp. and Polysiphonia sp. The low parasite species richness of S. variolatus contrasts with that of the continental congeneric species, S. viridis with 13 parasite species, and S. gigas with 13 species. Therefore, the diet of these fishes can not explain differences in their parasite composition, so it is possible that environmental conditions, and the distance between the location of Robinson Crusoe Island and the South American coast, had limited dispersal and distribution of hosts and parasites over time.

Key words: Juan Fernández Archipelago, parasite dispersion, Blenniid fishes, parasite species richness

\section{INTRODUCTION}

Each species belongs to a determined ecosystem and performs an important role within it. This role can be elucidated by establishing the types of interspecific relationships among the species of a certain habitat. In this context, the analyses of diets and parasites of species, allow the revealing parts of its function and importance in its community, and therefore, within the ecosystem.
Dietary studies of some taxonomic groups of organisms have allowed the understanding, for instance, of the trophic relationships among species (Angel \& Ojeda 2001) and the effects of predation on community structure (Town 1980, Ojeda \& Muñoz 1999), whereas parasitological studies allow us to investigate other aspects, such as trophic position of a host (Marcogliese 2003), the 
relation of parasites and the diet through host ontogeny (e.g., Muñoz et al. 2002, Amundsen et al. 2003), use of the habitat and geographical distribution (Marcogliese \& Cone 1997, Lafferty et al. 2008), and phylogenetic relationships between the hosts and their parasites (Poulin 1995, Vickery \& Poulin 1998).

In addition, dietary and parasitological studies provide basic biological knowledge about any species, and an understanding of the importance of their function and position in their habitats. Thus, it is surprising that these aspects have not been studied in many species yet. Particularly, worldwide fishes have been the most studied group of vertebrates with different kinds of scientific approaches, as aquaculture, fisheries, marine ecology and biotechnology (Muñoz \& Ojeda 1997). Nevertheless, fishes from insular ecosystems are hardly known because they are not abundant, and this makes sampling difficult. Besides, most such species do not have commercial importance, and that implies a low financial interest for fishing industries to gain knowledge about them (Pequeño \& Sáez 2004).

The present study considers the insular fish species Scartichthys variolatus, commonly called "borrachilla moteada". This blenniid fish inhabits mainly the intertidal and subtidal rocky zone, although it can reach down to $20 \mathrm{~m}$ depth. This species is distributed only around Juan Fernández Archipelago and Desventuradas Islands, in central and northern Chile, respectively. However, other Scartichthys species are distributed along the South American Pacific coast. It is known that insular systems have lower species diversity than habitats from continental systems. This observation has been based on the hypothesis that the colonization of an island by new species depends on the distance between that island and the continent (MacArthur \& Wilson 1967). Normally, dispersal strategies differ among species, being active (mobile organisms) or passive (organisms that depend on winds, currents or other organisms to move), so for distant new habitats, initial colonization is the most difficult matter. We can expect that diet and parasites of insular hosts are less diverse than those of congeneric continental hosts. Congeneric continental species, $S$. viridis and $S$. gigas, count with several studies of diet (Ojeda \& Muñoz 1999, Berríos \& Vargas 2004) and parasites (Díaz \& George-Nascimento 2002, Flores \& George-Nascimento 2009, Muñoz \& Cortés 2009, MuñozMuga \& Muñoz 2010). The diet of these fishes is mostly based on algae, and metazoans parasite richness has been ranged between 8 (Díaz \& George-Nascimento 2002) and 14 species (Muñoz-Muga \& Muñoz 2010). The biology of Scartichthys variolatus is completely unknown. There

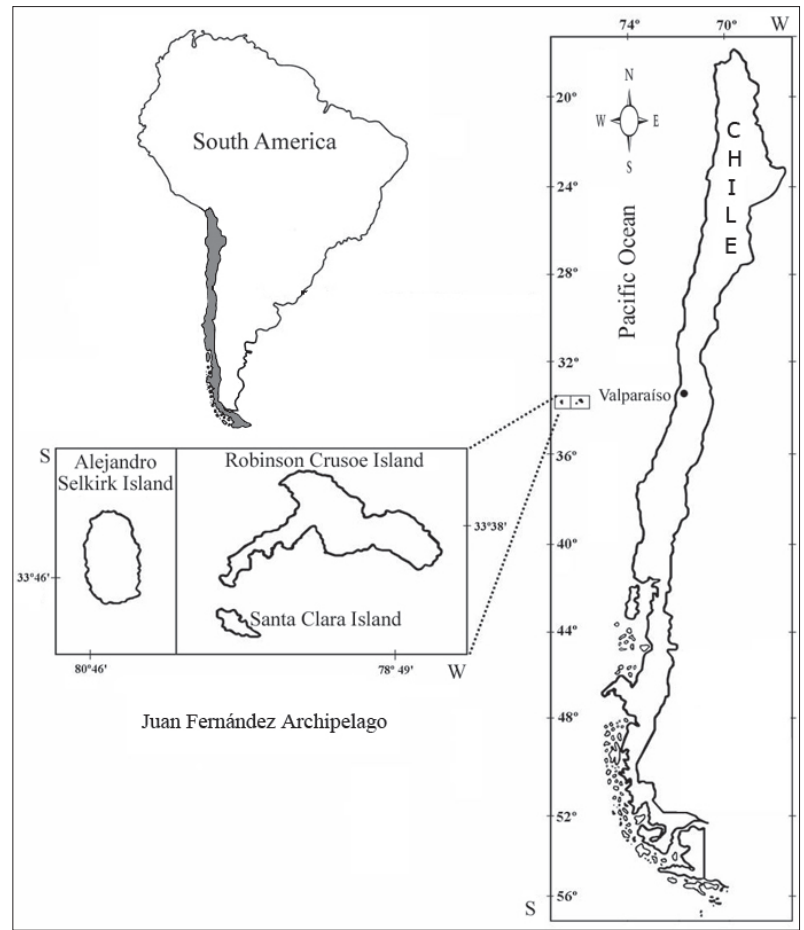

Figure 1. Area of study and sampling localities in the Robinson Crusoe Island, Juan Fernández Archipelago off central Chile / Área de estudio y localidades de muestreo, en la Isla Robinson Crusoe del Archipiélago Juan Fernández, frente a Chile central

has also been another species, $S$. crapulatus recorded for a specific locality in central Chile; however, the validity of this species is in doubt due to its morphological similarity to S. viridis (Williams 1990), so this species is not considered in this study. Therefore, the main objectives of this study are: 1) to analyze the dietary and parasitic composition of $S$. variolatus and 2) to determine if the diet and parasites of this fish differ from its two congeneric species.

\section{Material AND Methods}

A total of 52 specimens of Scartichthys variolatus were collected between February and March $2008(\mathrm{n}=37)$, and between February and April of $2009(n=15)$, from the rocky intertidal zones of two close localities, Muelle de Piedra and El Palillo, off Robinson Crusoe Island located

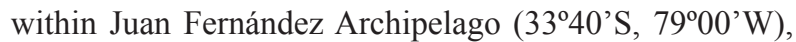
at approximately $700 \mathrm{~km}$ from the coast of central Chile (Fig. 1). Fish were captured in the intertidal rocky pools by hand and nethands, during low tide. The specimens collected were taxonomically identified using the key for description of Scartichthys species provided by Williams (1990). After that, the fishes identified as S. variolatus, were individually placed in plastic bags, and then frozen 
to be transported to the laboratory, at Universidad Andrés Bello, Santiago (continental Chile). Subsequently, the fish were defrosted, measured for total body length $(0.1$ $\mathrm{cm}$ precision), and then diet and parasites were analyzed according to the following procedures:

\section{Diet Analysis}

The digestive tract of each fish was removed separated from the body and then dissected. The content was sifted in a filter net $(0.5 \mu \mathrm{m}$ mesh size $)$. The food content was then collected and kept in vials in $10 \%$ formalin. When possible, the identification of each dietary item was to species-level, and supported by scientific articles on the intertidal biodiversity of the Juan Fernández Archipelago published by Ramírez \& Osorio (2000). Food items of each fish were weighed to a precision level of $0.01 \mathrm{~g}$.

The frequency of occurrence (FO) and weight (W) of each food item was calculated. Both indices were expressed in percentage and were only considered for individuals with food contents in the gut (Hyslop 1980).

The percentage similarity index, PSI (Hallacher \& Robert 1985) and that Jaccard's index (J) (Brower \& Zar 1984) were used to compare the diet of $S$. variolatus between 2008 and 2009 in order to determine the similarity of both samples. The percentage of similarity index is defined as: $\mathrm{PSI}=\mathrm{SUM}$ $\left(\min \mathrm{P}_{i}\right)$, where $\mathrm{P}_{i}=$ to the proportion of $\mathrm{W}$ or FO of an $i$ food item respect to total $\mathrm{W}$ or FO in the fish sample. Jaccard's index is defined by the following equation: Jaccard $=\mathrm{a} /$ $(a+b+c)$, where " $a$ " is assigned when an item is present in both samples, "b" is assigned when an item is present in one of the samples (i.e., year 2008) and "c" when it is present only in the other sample (i.e., year 2009). Values of both indices, PSI are between 0 and $100 \%$, and Jaccard is between 0 and 1 , corresponding to the lowest or highest similarity, respectively, between samples.

\section{Analysis OF PARASITES}

Each fish was examined for parasites: body surface, fins, oral cavity and gills were examined for ectoparasites, whereas digestive tract, muscles, and visceral organs were examined for endoparasites. All the parasites obtained were preserved in $10 \%$ formalin prepared in saline solution. The infracommunity descriptors utilized for this study were prevalence (percentage of hosts parasitized) and intensity (number of parasites per host parasitized only) (Bush et al. 1997).

The prevalences of parasitic species were compared with different years by a contingency table of $2 \times 2$ through a Fisher's Test (Zar 1996). The parasitic intensity was not compared with different years given to the low number of fish parasitized.

\section{DIET AND PARASITES OF SCARTICHTHYS SPP.}

Diet information for $S$. viridis and $S$. gigas was obtained from Ojeda \& Muñoz (1999) and Berríos \& Vargas (2004), whereas the parasitological information of these two species was obtained from Díaz \& George-Nascimento (2002) and Flores \& George-Nascimento (2009). We did not considered the information given by Muñoz-Muga \& Muñoz (2010) because they recorded new parasites species that may be overlooked in previos studies. There is information of parasites in localities from the northern and central Chile for $S$. viridis, so both studies were considered for the present analysis (Table 1). The PSI was calculated for frequency of occurrence of the food items, prevalence and mean of parasitic intensity, to know how similar Scartichthys spp. in diet and parasites are. Moreover, cluster analyses, through the similarity coefficient of Bray Curtis and the single link algorithm (McGarigal et al. 2000), were also performed on these biological information previously transformed $(\arcsin (\mathrm{x})$ for $\% \mathrm{FO}$ of diet and prevalence of parasites; $\log _{10}(\mathrm{x})$ for parasitic intensity). Then, a dendrogram display was constructed to show the percentage of similarity, in diet and parasites, among the three Scartichthys species used in these analyses.

\section{RESUlTS}

The total length of $S$. variolatus ranged between 5.6 and $23.6 \mathrm{~cm}$. There was a high frequency of fish measured between 5 and $10 \mathrm{~cm}$ in body length $(\mathrm{n}=24)$, and between 11 and $18 \mathrm{~cm}(\mathrm{n}=18)$. The dietary spectrum of $S$. variolatus was composed of 15 items, predominantly represented by algae $(\mathrm{W} \%=98.9 \%)$, and the remainder by invertebrates (Table 2). The algae Polysiphonia sp. and Chaetomorpha sp. were the most frequent with values of $35.3 \% \mathrm{FO}$ and $26.2 \%$ FO respectively; and abundant species (measured as weight) of $90.4 \% \mathrm{~W}$ and $69.2 \% \mathrm{~W}$, respectively (Table 2). The fish diet obtained in 2008 and 2009 had a similar composition, showing a high Jaccard's index $(\mathrm{J}=0.93)$ (Table 2). Similarly, the PSI had a high value between years when considering the frequency of occurrence (PSI $=100)$ and the weight of food items (PSI =90).

Only two fish specimens (3.85\% of prevalence), from the sample 2009, were parasitized out of 52 specimens examined. These two specimens had 20.2 and $23.1 \mathrm{~cm}$ of body length. Only six parasite individuals were collected, all of them belong to one species, the nematode Pseudodelphis 
Table 1. Parasite species recorded (X) in Scartichthys spp. for northern and central Chile / Especies de parásitos registrados (X) en Scartichthys spp. para el norte y centro de Chile

\begin{tabular}{|c|c|c|c|c|c|}
\hline \multirow[t]{2}{*}{ Parasitic taxa } & & \multicolumn{2}{|c|}{ Northern Chile } & \multicolumn{2}{|c|}{ Central Chile } \\
\hline & & S. viridis* & S. gigas* & S. viridis $\dagger$ & S. variolatus \\
\hline Hirudinea & Piscicolidae gen. sp. & & & $\mathrm{X}$ & \\
\hline \multirow[t]{4}{*}{ Copepoda } & Lepeophtheirus sp. & $\mathrm{X}$ & $\mathrm{X}$ & $\mathrm{X}$ & \\
\hline & Acanthochondria sicyasis & $\mathrm{X}$ & $\mathrm{X}$ & $\mathrm{X}$ & \\
\hline & Caligus sp. & $\mathrm{X}$ & $\mathrm{X}$ & & \\
\hline & Trifur sp. & $\mathrm{X}$ & $X$ & & \\
\hline \multirow[t]{2}{*}{ Monogenea } & $\begin{array}{l}\text { Microcotyle sp. (or } \\
\text { Paramicrocotyle moyanoi) }\end{array}$ & $\mathrm{X}$ & $\mathrm{X}$ & $\mathrm{X}$ & \\
\hline & Neobenedenia sp. (or N. melleni) & & $\mathrm{X}$ & $\mathrm{X}$ & \\
\hline \multirow[t]{4}{*}{ Digenea } & Lecitastheridae gen.sp. & $\mathrm{X}$ & $\mathrm{X}$ & $\mathrm{X}$ & \\
\hline & Monascus sp. & $\mathrm{X}$ & $\mathrm{X}$ & & \\
\hline & Megasolena sp. + & $\mathrm{X}$ & $\mathrm{X}$ & $\mathrm{X}$ & \\
\hline & Proctoeces sp. & $\mathrm{X}$ & $\mathrm{X}$ & & \\
\hline Acanthocephala & Corynosoma sp. & $\mathrm{X}$ & $\mathrm{X}$ & & \\
\hline \multirow[t]{2}{*}{ Nematoda } & $\begin{array}{l}\text { Pseudodelphis chilensis (or } \\
\text { Spirurida gen. sp.) }\end{array}$ & $\mathrm{X}$ & $\mathrm{X}$ & $\mathrm{X}$ & $\mathrm{X}$ \\
\hline & Johnstonmawsonia sp. & $\mathrm{X}$ & $\mathrm{X}$ & & \\
\hline Cestoda & Lacistorhynchus sp. & $X$ & & & \\
\hline
\end{tabular}

* Data from Flores \& George-Nascimento (2009); † Data from Díaz \& George-Nascimento (2002); * present study;

+ See Muñoz-Muga \& Muñoz (2010)

chilensis, recently described by Muñoz (2010). No significant difference was found in the prevalence of the nematode between the two sampling years, 2008 and 2009 (Fisher's Test, $P=0.08$ ). The average intensity of the nematode was three.

Relating to the analyses of similarity of the diet and parasites among Scartichthys spp., we found that $S$. variolatus had a diet more similar to $S$. viridis $(58.9 \%)$ than S. gigas (27.8\%) (Table 2) whereas the parasite composition was more similar between $S$. viridis and $S$. gigas, but both species greatly differed in parasites from $S$. variolatus (Table 3). These observations are also supported by the cluster analyses; medium similarity in diet among species (Fig. 2A), but different parasitic intensity and prevalence of infection in $S$. variolatus than in the other two species, independent of these two fishes being from different localities (Fig. 2B, C).

\section{Discussion}

Scartichthys variolatus is essentially herbivorous, similar to other two congeneric species in algal composition of its diets (Ojeda \& Muñoz 1999, Cáceres \& Ojeda 2000, Berríos \& Vargas 2004), although some differences occurred for particular items. For example, Polysiphonia sp. comprised $35.3 \% \mathrm{~W}$ in $S$. variolatus and $7.1 \% \mathrm{~W}$ in $S$. viridis (Ojeda \& Muñoz 1999), whereas Chaetomorpha firma comprised $26.2 \% \mathrm{~W}$ in S. variolatus and $0.1 \%$ in $S$. viridis. The diet between $S$. gigas (see Berríos \& Vargas 2004) and S. variolatus differed in \%FO for several food items, such as Chaetomorpha sp., Ulva sp., Gelidium sp., Pterocladida sp. and Ectocarpus sp. Invertebrates, although relatively frequent in Scartichthys spp., are small prey and are always in a low number, so these items are not important diet components for these fishes. The dietary differences observed among Scartichthys spp. may be due to food selectivity, as it has been demonstrated for S. viridis (Ojeda \& Muñoz 1999). Normally, congeneric species differed in ecological aspects at some degree, such as distribution and diet, because those reduce the competition among them. However, distribution and abundance of algae may be affected by environmental conditions, which consequently contribute to differential consumption of alga taxa among fish species and localities.

The parasite species richness of $S$. variolatus was low, being represented by only a single nematode specie (Pseudodelphis chilensis, also referred to as Spirurida gen. 
Table 2. Indices for weight (\%W) and frequency of occurrence (\%FO) of all diet items found in S. variolatus, for 2008 and 2009 and the total data / Indices de peso (\%W) y de frecuencia de ocurrencia (\%FO) de todos los itemes dietarios encontrados en S. variolatus, para los años 2008 y 2009 y el total de datos

\begin{tabular}{|c|c|c|c|c|c|c|}
\hline \multirow[t]{2}{*}{ Diet Items } & \multicolumn{2}{|c|}{$\% \mathrm{~W}$} & \multicolumn{2}{|c|}{$\% \mathrm{FO}$} & \multirow{2}{*}{$\begin{array}{l}\text { W\% } \\
\text { Total }\end{array}$} & \multirow{2}{*}{$\begin{array}{l}\% \mathrm{FO} \\
\text { Total }\end{array}$} \\
\hline & 2008 & 2009 & 2008 & 2009 & & \\
\hline \multicolumn{7}{|l|}{ Chlorophyta } \\
\hline Chaetomorpha firma & 25.5 & 28.4 & 62.1 & 87.0 & 26.2 & 69.2 \\
\hline Ulva sp. & 13.1 & 12.9 & 86.5 & 87.0 & 13.1 & 86.5 \\
\hline Cladophora sp. & 0.6 & 0.3 & 59.5 & 40.0 & 0.6 & 50.0 \\
\hline Chlorophyta unidentified & 2.7 & 3.4 & 89.2 & 66.7 & 2.8 & 82.6 \\
\hline \multicolumn{7}{|l|}{ Rhodophyta } \\
\hline Polysiphonia sp. & 35.5 & 34.6 & 86.5 & 100.0 & 35.3 & 90.4 \\
\hline Gelidium sp. & 10.4 & 10.7 & 64.9 & 53.3 & 10.4 & 61.5 \\
\hline Pterosiphonia sp. & 0.3 & 0.4 & 43.2 & 40.0 & 0.4 & 42.3 \\
\hline Liagora brachyclada & 1.1 & 0.7 & 40.5 & 46.7 & 1.0 & 42.3 \\
\hline Corallina officinalis var. chilensis & 2.5 & 1.8 & 51.4 & 53.3 & 2.3 & 51.2 \\
\hline Rhodophyta unidentified & 3.8 & 3.8 & 78.4 & 66.7 & 3.8 & 75.0 \\
\hline \multicolumn{7}{|l|}{ Phaeophyta } \\
\hline Distromium skottsbergii & 0.5 & 0.1 & 5.4 & 13.0 & 0.4 & 7.7 \\
\hline Dictyota phlyctaenodes & 0.1 & 0.0 & 5.4 & 0.0 & 0.1 & 3.8 \\
\hline Sphacelaria cirrosa & 1.5 & 0.3 & 29.7 & 13.0 & 1.3 & 25.0 \\
\hline Algae unidentified & 1.1 & 2.0 & 70.1 & 53.3 & 1.3 & 65.3 \\
\hline Total Algae & 98.8 & 99.4 & 100.0 & 100.0 & 98.9 & 100.0 \\
\hline Total Invertebrates & 1.2 & 0.6 & 64.9 & 46.7 & 1.1 & 59.6 \\
\hline
\end{tabular}

sp. in previous studies, Table 1), with low abundance and prevalence. This result contrasts with the greater parasite diversity of the congeneric continental species, S. gigas with 13 parasite species in samples from the northern Chile (Flores \& George-Nascimento 2009), and S. viridis with 13 (Flores \& George-Nascimento 2009) to 14 parasite species from the central zone of Chile (Muñoz \& Cortés 2009, Muñoz-Muga \& Muñoz 2010). Particularly, S. viridis is an intertidal fish species with one of the highest parasite richnesses (Muñoz \& Cortés 2009). In order to understand why $S$. variolatus has few parasites, we could consider the diversity of the diet and insular locality of the fish.

Some studies have found a relation between diet and parasite composition in fish (e.g., Muñoz et al. 2002).
Usually, invertebrates (specifically crustaceans) transmit endoparasites to fish, so when there are differences in crustacean composition in the host diet, there are differences in parasite composition as well (see Marcogliese 2003). However, Scartichthys spp. are herbivorous fish and their dietary differences are upon algae rather than invertebrates, so diet can not explain about differences in parasite diversity of these fish. We do not know the importance of algae in parasite transmission, although there are studies reporting that algae can contain some parasitic larval stages (Fels 2005) whereas other non-organism substrata may also be important for larval parasite transmission (Prinz et al. 2009). Unfortunately, life cycles of the parasites found in Scartichthys spp. are completely unknown, which makes difficult to figure out parasite transmission paths through 
Table 3. Percentages of similarity for diet (\%FO for each food item) and parasite species (mean intensity and \% of prevalence) among Scartichthys spp. The values are between 0 and 100 meaning the lowest and highest similarity respectively. NC: northern Chile, CC: central Chile; ICC: insular central Chile, are the localities where the biological information of fishes was from / Porcentajes de similitud para la dieta (\%FO para cada ítem dietario) y las especies parásitas (intensidad media y \% de prevalencia) entre las especies de Scartichthys spp. Los valores oscilan entre 0 y 100 indicando la más baja y más alta similitud respectivamente. NC: norte de Chile, CC: Chile central, ICC: Chile central insular

\section{S. viridis- NC S. gigas- NC S. variolatus- ICC S.viridis- CC}

Fish diet

S. viridis- NC

S. gigas- NC

S. variolatus- ICC

Mean parasite intensity

S. viridis- NC

S. gigas- NC

S. variolatus- ICC

S. viridis- CC

Parasitic prevalence

S. viridis- NC

S. gigas- NC

S. variolatus- ICC

S. viridis- CC
34.7

$---$

69.7

$---$

$-$

---

61.6

$---$

$---$
58.9

27.8

11.3

4.9

0.4

37.3

2.5

$---$

34.4

32.8

5.6



B) Mean parasite intensity

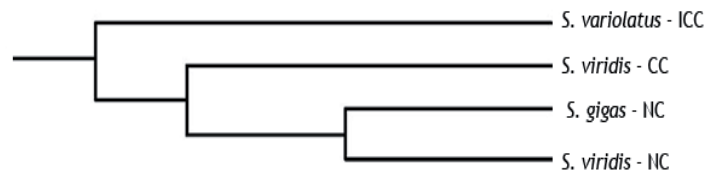

C) Prevalence

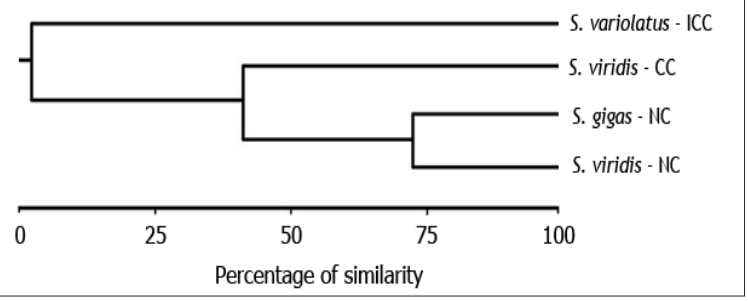

Figure 2. Dendrograms of similarity among 3 Scartichthys spp., based on: A) diet (\%FO for each item) and parasite species, B) intensity and C) prevalence. Locality abbreviations in Table 3 / Dendrogramas de similitud entre 3 especies de Scartichthys spp., basado en: A) dieta (\%FO de cada ítem), y las especies parásitas, B) intensidad media y C) prevalencia. Abreviaturas de localidades en Tabla 3 the host diet. Therefore, locality, focusing mainly in characteristics of insular and continental systems, could explain more about differences in parasites than considering the fish diet.

There are physical differences between insular and continental systems, such as currents, topography, oceanographic features, which affect the diversity of parasites. On one hand, the environmental characteristics first affect ectoparasites because they are directly in contact with the external host environment, usually this is detected by decreasing abundance or absence of ectoparasites (Kabata \& Ho 1981, Rohde \& Heap 1998). Ectoparasites were not found in S. variolatus, although they are common in two congeneric species from the continent (Flores \& George-Nascimento 2009, Muñoz-Muga \& Muñoz 2010). On the other hand, the parasite diversity is a reflection of the free-living species diversity in the place where a host lives because transmission of most parasites imply several hosts, so the greater species diversity, the greater parasite richness might also be (Poulin 2007, Luque \& Poulin 2007).

The coast of continental central Chile as well as Robinson Crusoe Island, from where the fishes were obtained for this study, has been characterized as a zone with great 
macroinvertebrate and algae diversity (see Lancellotti \& Vásquez 2000, Ramírez \& Osorio 2000). However, several littoral species have different distribution between the continent and the island, and some common species in the continent, such as bivalves and grey algae, are not present at the Island (Ramirez \& Osorio 2000). Different species composition and spatial distributions of the free-living species between localities may create different interactions and trophic webs, affecting parasite composition. On the other hand, Juan Fernández Archipelago, to which Robinson Crusoe Island belongs, is characterized by a singular system of marine currents (Pequeño \& Sáez 2000) that limit the distribution of $S$. variolatus with their continental congeneric species, so interactions among these fishes, and between fish and parasites, are infrequent. Moreover, parasite communities are prone to local extinction (Rohde 1984, Poulin \& Morand 2004, Poulin 2007), and these communities can be recovered if they are close to other sources (i.e., localities, hosts) that can collaborate with new parasite specimens (MacArthur \& Wilson 1967).

Scartichthys gigas is distributed from Panamá to northern Chile, S. viridis is distributed from Peru to central Chile, and $S$. variolatus is distributed only off islands of Chile (Juan Fernández Archipelago and Desventuradas Islands), so there is an overlap in distribution only between $S$. viridis and S. gigas, and none with S. variolatus (Williams 1990). It is probable that the long distance migration of an ancestral Scartichthys species to the island isolated specimens with then speciated into another distinct species, S. variolatus, which likely kept few parasites during its migration (see discussion about parasites speciation during migration of Merluccius spp. in Kabata \& Ho 1981). Although, there are a few studies about parasites from continental and insular hosts (Rohde 1984, Cressey 1986, Jones 1988, PardoGandarillas et al. 2007), there are many studies on mammals and birds which support the idea that species richness is lower in islands than the continent (MacArthur \& Wilson 1967, Carrascal \& Palomino 2002, Stephens \& Wiens 2003).

In conclusion, this study has shown that an insular fish species differs markedly in the composition of its parasitic fauna with respect to the congeneric continental species, even though these fishes have a relatively similar dietary composition composed largely of algae. Possibly, the Scartichthys ancestor lost most of its parasites during the migration to the islands, although if the parasites persisted during host dispersal, settlement and adaptation of the parasites in a new environment may not have been successful. Then, biotic and abiotic characteristics of the island could have negatively affect survivorship of those parasites that are normally found in continental Scartichthys spp.

\section{ACKNowledgments}

We thank R. Garcia-Huidobro for his help in the algae identification, P. Lagos by his support and help in field trips and Archipiélago Juan Fernández Foundation for assistance in the expedition to the island. Partial financial support by DIPUV-12/2008.

\section{LITERATURE CITED}

Amundsen P, R Knudsen, AM Kuris \& R Kristoffersen. 2003. Seasonal and ontogenetic dynamics in trophic transmission of parasites. Oikos 12: 285-293.

Angel A \& FP Ojeda. 2001. Structure and trophic organization of subtidal fish assemblages on the northern Chilean coast: the effect of habitat complexity. Marine Ecology Progress Series 217: 81-91.

Berríos V \& M Vargas. 2004. Estructura trófica de la asociación de peces intermareales de la costa rocosa del norte de Chile. Revista de Biología Tropical 52: 201-212.

Brower JE \& JH Zar. 1984. Field and laboratory methods for general ecology, 226 pp. WC Brown Publishers, Dubuque.

Bush AO, KD Lafferty, JM Lotz \& AW Shostak. 1997. Parasitology meets ecology on its own terms: Margolis et al. revisited. The Journal of Parasitology 83: 575-583.

Cáceres C \& FP Ojeda. 2000. Patrones de forrajeo en dos especies de peces intermareales herbívoros de las costas de Chile: efecto de la abundancia y composición química del alimento. Revista Chilena de Historia Natural 73: 253-260.

Carrascal LM \& D Palomino. 2002. Determinantes de la riqueza de especies de aves en las islas Selvagem y Canarias. Ardeola 49: 211-221.

Cressey RF. 1986. Biogeography of parasitic copepods. Syllogeus 58: 136-143.

Díaz F \& M George-Nascimento. 2002. Estabilidad temporal de las infracomunidades de parásitos en la borrachilla Scartichthys viridis (Valenciennes, 1836) (Pisces: Blenniidae) en la costa central de Chile. Revista Chilena de Historia Natural 75: 641-649.

Fels D. 2005. The effect of food on microparasite transmission in the waterflea Daphnia magna. Oikos 109: 360-366.

Flores $\quad \mathrm{K} \quad \& \quad \mathrm{M}$ George-Nascimento. 2009. Las infracomunidades de parásitos de dos especies de Scartichthys (Pisces: Blenniidae) en localidades cercanas del norte de Chile. Revista Chilena de Historia Natural 82: 63-71.

Hallacher L \& D Roberts. 1985. Differential utilization of space and food by the inshore rockfishes (Scorpaenidae: 
Sebastes) of Carmel Bay, California. Environmental Biology of Fishes 12: 91-110.

Hyslop EJ. 1980. Stomach contents analysis - a review of methods and their application. Journal of Fish Biology 17: 411-429.

Jones JB. 1988. Zoogeography of parasitic Copepoda of the New Zealand region. Hydrobiologia 167/168: 623-627.

Kabata Z \& J-S Ho. 1981. The origin and dispersal of hake (genus Merluccius: Pisces: Teleostei) as indicated by its copepod parasites. Oceanography and Marine Biology: an Annual Review 19: 381-404.

Lafferty K, S Allesina, M Arim, C Briggs, G De Leo, A Dobson, J Dunne, P Johnson, A Kuris, D Marcogliese, N Martinez, J Memmontt, P Marquet, J McLaughlin, E Mordecai, M Pascual, R Poulin \& D Thieltges. 2008. Parasites in food webs: the ultimate missing links. Ecology Letters 11: 533-546.

Lancellotti D \& JA Vásquez. 2000. Biodiversidad de macroinvertebrados submareales de la costa chilena: patrones zoogeográficos. Revista Chilena de Historia Natural 73: 99-129.

Luque JL \& R Poulin. 2007. Metazoan parasite species richness in Neotropical fishes: hotspots and the geography of biodiversity. Parasitology 134: 865-878.

MacArthur RH \& EO Wilson. 1967. The theory of Island biogeography, 203 pp. Princeton University Press, Princeton.

Marcogliese DJ. 2003. Food webs and biodiversity: are parasites the missing link? The Journal of Parasitology 89: S106-S113.

Marcogliese DJ \& D Cone. 1997. Food webs: a plea for parasites. Trends in Ecology and Evolution 12: 320-325.

McGarigal K, S Cushman \& S Stafford. 2000. Multivariate statistics for wildlife and ecology research, 279 pp. Springer Science-Business Media, New York.

Muñoz AA \& FP Ojeda. 1997. Feeding ecology and guild structure of a rocky intertidal fish assemblage of Central Chile. Environmental Biology of Fishes 49: 471-479.

Muñoz G. 2010. A new species of Pseudodelphis (Dracunculoidea: Guyanemidae) in the intertidal fish Scartichthys viridis (Blenniidae) from Central Chile. The Journal of Parasitology 96: 152-156.

Muñoz G \& Y Cortés. 2009. Parasite communities of a fish assemblage from the intertidal rocky zone of central Chile: similarity and host specificity between temporal and resident fish. Parasitology 136: 1291-1303.

Muñoz-Muga P \& G Muñoz. 2010. Parasite communities of Scartichthys viridis (Valenciennes, 1836) (Pisces:
Blenniidae) from central Chile: locality vs. host length. Revista de Biología Marina y Oceanografía 45: 165-169.

Muñoz G, V Valdebenito \& M George-Nascimento. 2002. La dieta y la fauna de parásitos metazoos del torito Bovichthys chilensis Regan 1914 (Pisces: Bovichthydae) en la costa de Chile centro-sur: variaciones geográficas y ontogenéticas. Revista Chilena de Historia Natural 75: 661-671.

Ojeda FP \& A Muñoz. 1999. Feeding selectivity of the herbivorous fish Scartichthys viridis: effects on macroalgal community structure in a temperate rocky intertidal coastal zone. Marine Ecology Progress Series 184: 219-229.

Pardo-Gandarillas MC, K González, CM Ibáñez \& M George-Nascimento. 2007. Parasites of two deep-sea fish Coelorynchus chilensis (Pisces: Macrouridae) and Notacanthus sexspinis (Pisces: Notacanthidae) from Juan Fernández Archipelago, Chile. JMAB2 Biodiversity Records [on-line]: < doi:10.1017/S1755267207007944>

Pequeño G \& S Sáez. 2000. Los peces litorales del archipiélago de Juan Fernández (Chile): endemismo y relaciones ictiogeográficas. Investigaciones Marinas 28: 27-37.

Pequeño G \& S Sáez. 2004. Peces del crucero Cimar 6- Islas (II): La familia Blenniidae en las Islas Desventuradas, Chile (Ostheichthyes: Perciformes). Ciencia y Tecnología del Mar 27: 113-119.

Poulin R. 1995. Phylogeny, ecology, and the richness of parasite communities in vertebrates. Ecological Monographs 65: 283-302.

Poulin R. 2007. Evolutionary ecology of parasites, 332 pp. Princeton University Press, Princeton.

Poulin R \& S Morand. 2004. Parasite biodiversity, 216 pp. Smithsonian Books, Washington.

Prinz K, TC Kelly, RM O'Riordan \& SC Culloty. 2009. Non-host organisms affect transmission processes in two common trematode parasites of rocky shores. Marine Biology 156: 2303-2311.

Ramírez ME \& C Osorio. 2000. Patrones de distribución de macroalgas y macroinvertebrados intermareales de la isla Robinson Crusoe, archipiélago de Juan Fernández, Chile. Investigaciones Marinas 28: 1-13.

Rohde K. 1984. Zoogeography of marine parasites. Helgolander Meeresuntersuchungen 37: 35-52.

Rohde K \& M Heap. 1998. Latitudinal differences in species and community richness and in community structure of metazoan endo- and ectoparasites of marine teleost fish. International Journal for Parasitology 28: 461-474.

Stephens PR \& JJ Wiens. 2003. Explaining species richness from continents to communities: the time-for-speciation effect in emydid turtles. The American Naturalist 161: 112128. 
Town J. 1980. Diet and food preference of intertidal Astrostole scabra (Asteroidea: Forcipulata). New Zealand Journal of Marine \& Freshwater Research 14: 427-435.

Vickery W \& R Poulin. 1998. Parasite extinction and colonization and the evolution of parasite communities: a simulation study. International Journal for Parasitology 28: 727-737.
Williams JT. 1990. Phylogenetic relationships and revision of the blenniid fish genus Scartichthys. Smithsonian Contributions to Zoology 492: 1-30.

Zar J. 1996. Biostatistical analysis, 660 pp. Prentice-Hall, Englewood Cliffs.

Recibido el 19 de marzo de 2010 y aceptado el 20 de mayo de 2010 